\title{
Editorial
}

\section{A game of democracy. Science museums for the governance of science and technology}

Luckily enough, more democracy is always called for. Even in countries that can truly be described as democratic. And democracy (which is a constant reference in these pages) is increasingly related to knowledge, be it about whether growing GMOs, starting nuclear energy production or allowing the choice of a child's gender through IVF techniques. The need to make democratic decisions on controversial issues, which increasingly imply scientific and technological knowledge, comes from the bottom, as citizens voice - sometimes even vehemently - the desire to express themselves. But it also comes from the top: local, national and supranational administrations wish to avoid being caught unawares by the people's rejection of the solutions adopted. But it also comes, as it were, from the sides: the scientific community and other stakeholders are increasingly aware they have to negotiate with society the choices that involve them, also when it comes to the direction the so-called pure research may take.

But where does this democratic debate take place? The situation is quite complicated, and still under evolution. When the time comes for a referendum, or party voting, it is already too late to talk about debating. Scientific-technological governance does require exchange and discussion of information, opinions, beliefs, experiences, whereas voting is a one-off action, when choices have already been made. Granted, old media still are the main source of information, and therefore are highly involved in shaping opinions, but are quite unsuitable to provide the sort of insight needed for truly informed decision-making, let alone to give voice to all the opinions. On the other hand, the Internet, which certainly is taking them over in the habits of many people, is still apparently a place where to find confirmations rather than refutations. We could even brand it 'info-shopping', quite similarly to 'doctor-shopping', as some call it: on the Internet, those thinking vaccines are dangerous will look for - and find - similar views, with any related confirmations coming from institutes, associations, documents, research results...

Good scientific education - which provides the basic conceptual instruments to understand the processes underpinning scientific knowledge production - can certainly help building a full scientifictechnological citizenship, i.e. the capability to face the complex issues of our times. But it is naïve to think that working on basic education would solve the problem of a full democracy: attitudes, stances, emotions, experiences, expectations and fears are not always directly related to knowledge. In addition, new issues, with their heritage of new variables, constantly arise and will continue to arise.

So, where and how to stage a deep dialogue to include non-experts, stakeholders, policy-makers, scientists, manufactures...?

For over a decade, the European Commission, within the framework of the Science and Society programme, ${ }^{1}$ has been funding international projects devoted especially to the design, the experimentation and the study of participation methods (sometimes also deliberating methods), such as consensus conferences or scenario workshops. ${ }^{2}$ Many of these experiments have been taking place in or in any case involving - science museums and science centres: Cipast, Decide, Dotik, Nanodialogue, Messengers, Meeting of minds, Alter-Net, Time for Nano, Nanototouch, Accent, Polka, are only some of this kind of projects funded by the Commission. ${ }^{3}$

What better place than museums and science centres to host the dialogue between science and society? A place that is felt by people of any age and education as familiar and unbiased. A welcoming, not judging, place people go to with trust, and to have fun and learn.

Benefiting from these assets, without disregarding the support to the renovation of scientific education, museums present themselves to society as "safe places for difficult conversations", namely "places where controversial issues related to the ethical, social and economic impact of research and of new technologies can be discussed in an open and informed way" (from the Toronto Declaration, signed in 2008 by four hundred science centres and museums across the world). ${ }^{4}$

Of course, the task is not easy, and museums have to face practical difficulties with no easy solution.

In the first place, the public of museums, though very large $(25,000$ visitors per day over the Christmas holidays at the Natural History Museum of London and 35,000 over the same period at the Cité des 
Sciences et de l'Industrie of Paris), does not represent the whole society yet. There is still much to do in terms of social inclusion.

Luigi Amodio, director of the Città della Scienza of Naples, at the forefront in Europe in its mission and activities, says: «Explicitly born from the need to connect science with common people, science centres are gradually regaining - after a crisis which depicted them simply as 'intelligent' fun places - an important function which does not only concern their educational and informational mission, but implies a real support to social inclusion, given that exclusion today involves, at least in rich countries, especially (though not exclusively) access to knowledge». ${ }^{5}$ Programmes aimed at this goal have been carried out basically all over the world: from the recruitment of young people from the favelas of Rio and from the Bronx of New York as scientific explainers (so that - beyond mere support - they can acquire some selfconfidence, and in many cases they get motivated to scientific careers), to the involvement of people belonging to particular religious or ethnic groups in the designing of exhibitions and events.

The second issue concerns the relation with the scientific community, which apparently still prioritise old communication channels (papers, radio and television). As Matteo Merzagora writes: “(...) science centres do organise debates on front-end current research, but have mostly failed to convince scientists to use them as a public stage on which, for example, to advocate for investment for the ITER reactor rather than for energy saving domestic appliances, or for string theory rather than loop quantum gravity research. These functions, essential for a dialogue to occur, are still mainly covered by the mass media, where the battles among scientific institutions to conquer space and value is clearly experienced by any science journalist". 6

But also to tackle this second communication gap, many museums are acting creatively, trying to establish more stable links with the world of research. One of the solutions adopted, for example, at the Natural History Museum of London, as well as the Deutsches Museum of Munich, is to bring scientists directly to the public, not only for conferences or science cafés, but also within exhibition areas: labexhibitions, where researchers work (part-time) in real time, so as to create an informal and constant exchange between researchers and visitors.

The third issue concerns policy makers. Similarly to what happens in the scientific community, also public administrators and other figures involved in policy-making, though acknowledging the educational role played by museums, funding their activities and attending events and programmes of different types, still do not consider them as places where to listen to public opinion and to directly face citizens. However, the divide among countries in this respect is very wide, and in northern European countries - which place a higher and systematic attention on public participation at any levels - there have been significant experiences. Not to mention that the lack of communication with decision makers is not an issue only affecting science museums, but for instance it is one of the main obstacles to the creation, in Europe, of the much coveted "knowledge society".

Finally, there is an issue concerning methods. As previously said, different participation formats are under experimentation, each of which has its pros and cons.

On one side, there are deliberating events, organised at European level by involving small yet representative groups of citizens. Their results - with some validity as a survey - are presented to policy markers, especially at EU level. However, the organizational costs of these events are very high, and their impact on the citizens' mass is virtually non-existent. If, on the other hand, one wants to operate with large numbers, then much more effectiveness is provided by participation games, democratic debate labs based on "lighter" formats, such as focus groups, card games and role play. Also in this case small groups are involved, but the cost is very low, and the activities may be repeated countless times, exactly as it happens for those more traditional scientific laboratories that are part of the daily schedule of each museum or science centre. An example is the programme "Fatti un'opinione" ("Make up your mind"), which comprises workshops regularly scheduled at the Museo Nazionale della Scienza e della Tecnologia of Milan. ${ }^{7}$

As they do not require any special equipment, participation games can also be used outside the museum, potentially everywhere, including private homes: they usually require only small tables, cards and/or the game instructions and, not always, a facilitator. They have been used in prisons, as well as with homeless people, at school and in libraries. ${ }^{8}$

These instruments allow to achieve the following results:

- $\quad$ scientific information is provided

- $\quad$ interrelations among science, technology and society are presented 
- $\quad$ people are helped to shape an opinion, as they are presented with other people's opinions and points of view

- a positive model of democratic debate, structured yet open, is presented.

The pros and cons of participation games are widely discussed in the commentary of this issue, especially as concerns the Decide ${ }^{9}$ game, the most successful and widespread in Europe and beyond. In any case, this looks like a promising path that - based on its increasing success - may create, from the bottom and within small local networks, a social fabric made up of autonomous knots, which are also autonomously interconnected. This fabric, from city to city, nation to nation, may transfer materials, techniques, but also ideas and information, in a centralised yet effective way that characterises also the web 2.0, and therefore somehow also our age.

Paola Rodari

\section{Notes and references}

${ }^{1}$ Monitoring Activities of Science in Society in Europe: Challenging Futures of Science in Society - Emerging trends and cuttingedge issues, European Commission, 2009;

Global Governance of Science - Report of the Expert Group on Global Governance of Science to the Science, Economy and Society Directorate, Directorate-General for Research, European Commission 2009.

2 S. Joss and J. Durant eds. (1995), Public Participation in Science: The Role of Consensus Conferences in Europe, London, Science Museum;

R. Hagendijk and A. Irwin (2006), Public Deliberation and Governance: Engaging with Science and Technology in

Contemporary Europe, Minerva 44(2): 167-184.

3 For our most recent projects, please go to the Ecsite website, the European network of museums and science centres: http://www.ecsite.eu/?p=85

4 http://www.5scwc.org/TheTorontoDeclaration/tabid/133/Default.aspx

5 L. Amodio (2004), Scienza, tecnologia e società in Europa: quale ruolo per i science centre?, in N. Pitrelli e G. Sturloni (a cura. di), La comunicazione della scienza. Atti del I e II convegno nazionale, Zadigroma, Roma 2004.

6 M. Merzagora (2008), Evolving dialogue, Ecsite newsletter, n. 74 spring 2008.

7 S. Calcagnini (2007), Debating as an educational method to science and citizenship, Jcom 06(03): C1.

8 For an example of materials designed specifically for high secondary schools, please go to the website of the British project Citizens Science, funded by Wellcome Trust: http://www.at-bristol.org.uk/cz.

9 http://www.playdecide.eu.

How TO CITE: $\quad$ P. Rodari, A game of democracy. Science museums for the governance of science and technology, Jcom 09(02) (2010) E. 